Available online at GSC Online Press Directory

GSC Biological and Pharmaceutical Sciences

e-ISSN: 2581-3250, CODEN (USA): GBPSC2

Journal homepage: https://www.gsconlinepress.com/journals/gscbps

(RESEARCH ARTICLE)

\title{
Composition, distribution and relative abundance of fishes linked to fringing reefs of southern Veracruz, Gulf of Mexico
}

\author{
Carlos González-Gándara * \\ Laboratorio de Arrecifes Coralinos, Facultad de Ciencias Biológicas y Agropecuarias, Universidad Veracruzana. Carr. \\ Tuxpan-Tampico Km 7.5. CP 92860. Col. Universitaria. Tuxpan Veracruz. Tel/Fax: 527838344350.
}

Publication history: Received on 13 August 2020; revised on 26 August 2020; accepted on 29 August 2020

Article DOI: https://doi.org/10.30574/gscbps.2020.12.2.0268

\begin{abstract}
The biological knowledge of the reef communities of southern Veracruz is fundamental, because, according to the Mexican National Commission for the Knowledge and Use of Biodiversity, they are part of a priority marine zone. This paper describes the ichthyological components of the southern Veracruz fringing reefs, including information on abundance and distribution. 146 random visual censuses were conducted in 5 habitats characterized by the dominant benthic groups and environmental features (structural complexity, transparency, and depth). In each census, fish species were identified and their abundance estimated using 6 ordinal categories. Subsequently, the similarity of the ichthyologic communities with the Jaccard Index was determined. The reef formations of southern Veracruz include 91 fish species, 58 genera, and 31 families. According to their relative abundance, $25 \%$ of the fish species were catalogued as rare, $25 \%$ as uncommon, $23.9 \%$ as occasional, and $22.7 \%$ as common or abundant. The most abundant fish species were: Stegastes adustus, Halichoeres bivittatus, Thalassoma bifasciatum, Bodianus rufus, and Ophioblennius maclurei while, the families: Epinephelidae, Gobiidae, and Scaridae showed a scarce richness and abundance. The benthic attributes (coral cover) and environmental features of habitats were related to the richness, components, and relative abundance of fishes.
\end{abstract}

Keywords: Checklist; Fish community; Fringing reefs; Veracruz; Gulf of Mexico

\section{Introduction}

According to their geomorphology, the coral formations of the Veracruz coast include 3 types of reefs: platform, fringing, and submerged banks [1]. In fringing reefs, discrete environments distributed in a depth gradient have been detected. This has been used to describe the ichthyological distribution patterns given their differences in benthic and geomorphological attributes [2]. Coral cover, structural complexity, and depth are variables that most influence fish richness and abundance $[3,4,5]$.

The fish communities associated with platform-type reefs of Veracruz are well documented. However, the ichthyofauna of the fringing reefs is little known, because there is only one study in Hornos Reef [6] located in the center of Veracruz. In the south of Veracruz, there is a series of isolated reef structures that form "El Sistema Arrecifal Los Tuxtlas" (SAT), which was proposed as a marine protected area [7]. These fringing reefs are too included in a priority marine zone of Mexico [8]. This condition implies the need to know their biotic diversity. The biological components of the strip of reefs located in front of the municipalities of Mecayapan and Tatahuicapan, Veracruz are little known. For these reefs, there are recorded, 86 species of mollusks [9], 26 species of echinoderms [10], and a non-native fish species [11].

\footnotetext{
* Corresponding author: Carlos González-Gándara, Tel/Fax: 527838344350; Email: cggandara@hotmail.com

Laboratorio de Arrecifes Coralinos, Facultad de Ciencias Biológicas y Agropecuarias, Universidad Veracruzana. Carr. Tuxpan-

Tampico Km 7.5. CP 92860. Col. Universitaria. Tuxpan Veracruz.
} 
The knowledge of fish communities in coral reefs is one of the most important to define conservation strategies in marine protected areas. For that, this research describes the ichthyofauna of the fringing system located in front of the municipalities of Mecayapan and Tatahuicapan, Veracruz, including information on its distribution and relative abundance in 5 habitats.

\section{Material and methods}

This study was carried out in the fringing reefs located in front of the municipalities of Mecayapan and Tatahuicapan, Veracruz $\left(18^{\circ} 30^{\prime} 00^{\prime \prime} \mathrm{N}, 94^{\circ} 50^{\prime} 00^{\prime \prime} \mathrm{W}\right.$ ) (Figure 1). The reef structure is $3.5 \mathrm{~km}$ long and ranges in depth from 2 to $12 \mathrm{~m}$ [7].

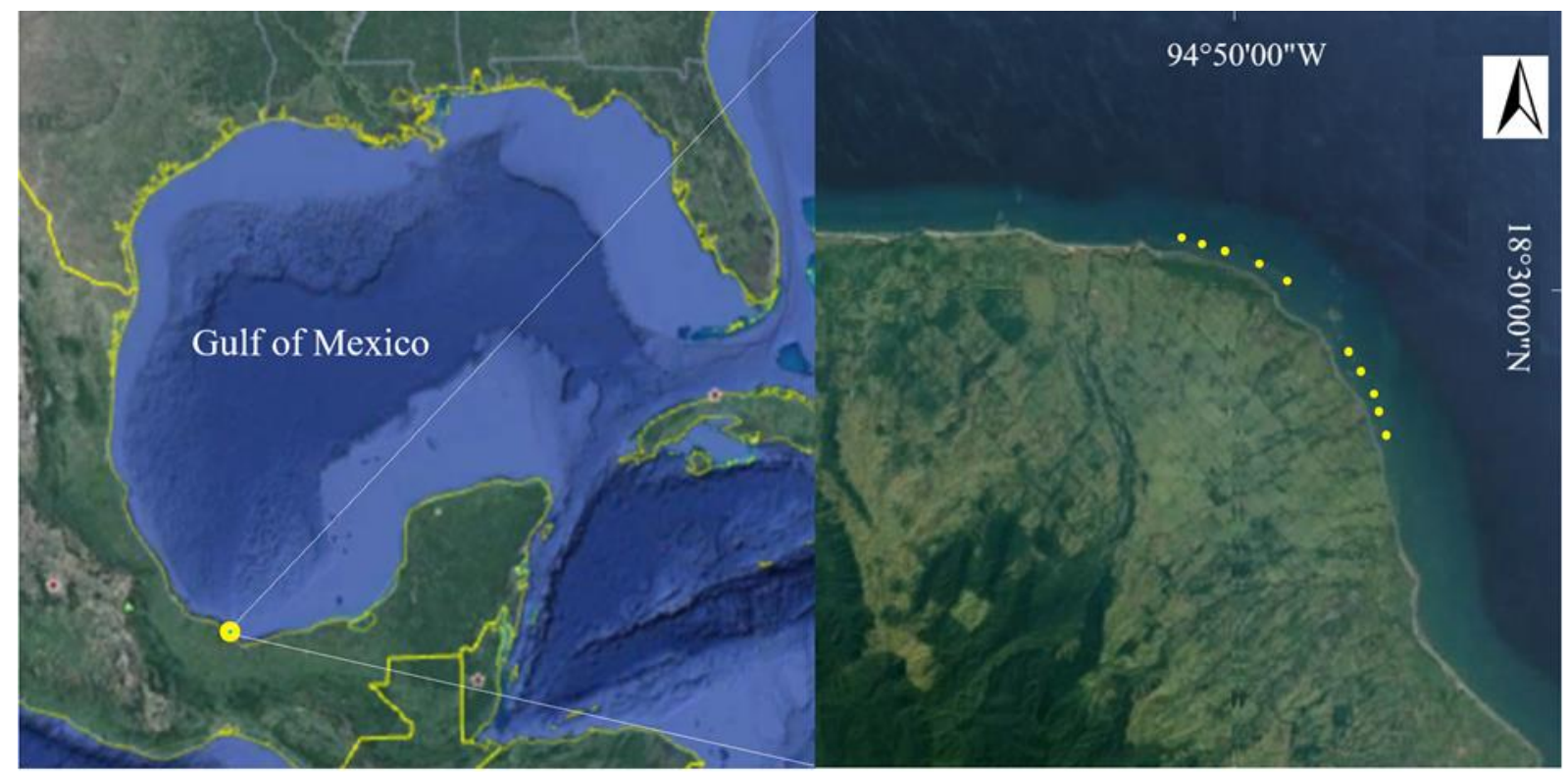

Figure 1 Geographic location of the fringing reefs of southern Veracruz, Gulf of Mexico. Yellow dots corresponded to sampling sites. This map was taken from Google Earth.

From June to September 2013, 146 visual surveys were conducted using the roving diver technique (30 minutes) with SCUBA diving equipment. The sampling was distributed systematically in 10 sites over the reef strip (Figure 1). In each census, fish species were identified using their morphological and coloration patterns that distinguish them. Fish species were ordered systematically according to Nelson et al. [12] criteria for supra-generic categories, while genera and families were organized alphabetically. The revision of nomenclature followed the proposal of Fricke et al. [13] and the FishBase [14]. Non-parametric models (Chao 2, Jack 1, Jack 2, and Bootstrap) were used to estimate the potential richness with EstimateS version 9.0 [15].

The habitats of fringing reef studied were classified from dominant benthic groups (algae, sponges, corals, and zoanthids) or structures (boat). This information was complemented with data on the structural complexity of reefs and transparency of water, using an ordinal scale with 3 categories (high, intermediate, and low) and with depth data obtained with a dive computer, categorizing it into 2 groups: $<5 \mathrm{~m}$ and $>5 \mathrm{~m}$.

Fish species were classified according to their relative abundance in the following categories: Rare ( 1 record during all expedition); Uncommon ( $<5$ total records); Occasional ( $\sim 20$ total records at multiple dive sites); Common (recorded at most dive sites); Locally common (scores to tens at 1 to 2 dive sites) and Abundant (tens to hundreds at most dive sites). The presence-absence data by habitat were used to compare the fish communities using the Jaccard Index through the PAST program [16].

\section{Results and discussion}

The ichthyological fauna associated with the fringing reefs of southern Veracruz described for the first time in this work, it is composed of 91 species belonging to 58 genera and 31 families (Table 1). 
Table 1 List of fishes observed on 5 habitats on the southern fringing reef of Veracruz, Gulf of Mexico.

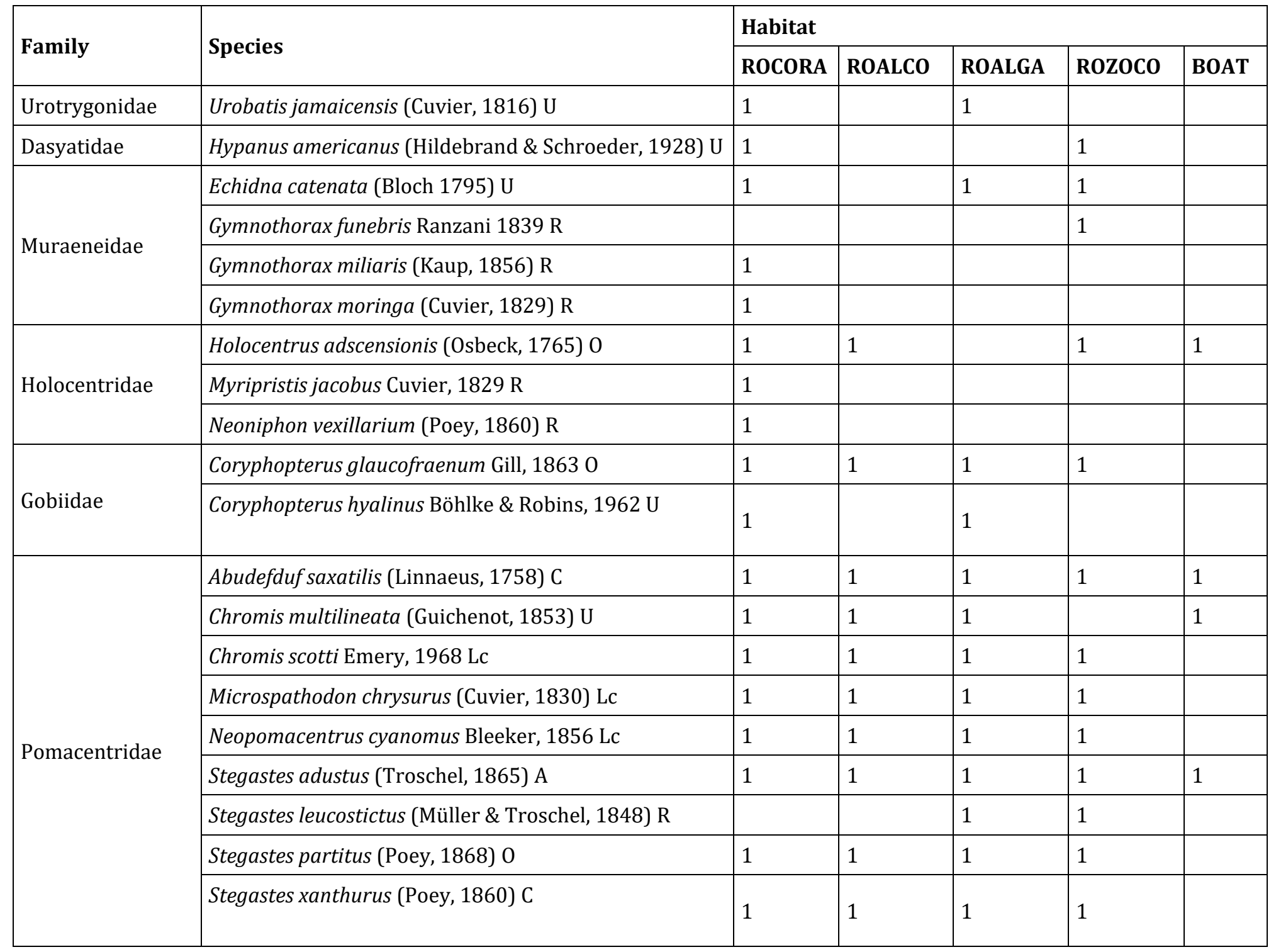


GSC Biological and Pharmaceutical Sciences, 2020, 12(02), 217-228

\begin{tabular}{|c|c|c|c|c|c|c|}
\hline \multirow{4}{*}{ Blenniidae } & Hypsoblennius invemar Smith-Vaniz \& Acero 1980 R & & & & & 1 \\
\hline & Ophioblennius macclurei (Silvester, 1915) C & 1 & 1 & 1 & 1 & 1 \\
\hline & Parablennius marmoreus (Poey, 1876) 0 & 1 & 1 & 1 & 1 & \\
\hline & Scartella cristata (Linnaeus, 1758) R & & & & 1 & \\
\hline \multirow{2}{*}{ Labrisomidae } & Labrisomus nuchipinnis (Quoy \& Gaimard, 1824) C & 1 & 1 & 1 & 1 & 1 \\
\hline & Malacoctenus triangulatus Springer, 1959 R & & & 1 & & \\
\hline \multirow{8}{*}{ Carangidae } & Caranx bartholomaei Cuvier, 18330 & 1 & 1 & 1 & 1 & \\
\hline & Caranx crysos (Mitchill, 1815) U & 1 & & 1 & & \\
\hline & Caranx hippos (Linnaeus, 1766) R & 1 & & & & \\
\hline & Caranx latus Agassiz, $1831 \mathrm{R}$ & & & 1 & & \\
\hline & Caranx ruber Bloch, 17930 & 1 & 1 & 1 & 1 & 1 \\
\hline & Decapterus macarellus (Cuvier, 1833) R & & & & & 1 \\
\hline & Seriola rivoliana Valenciennes, $1833 \mathrm{R}$ & & & 1 & & \\
\hline & Trachinotus goodei Jordan \& Evermann, 1896 U & 1 & 1 & & & \\
\hline Sphyraenidae & Sphyraena barracuda (Walbaum, 1792) 0 & 1 & 1 & 1 & 1 & \\
\hline \multirow{6}{*}{ Labridae } & Bodianus rufus (Linnaeus, 1758) C & 1 & 1 & 1 & 1 & 1 \\
\hline & Halichoeres bivittatus (Bloch, 1791) A & 1 & 1 & 1 & 1 & 1 \\
\hline & Halichoeres burekae Weaver \& Rocha, 2007 C & 1 & 1 & 1 & 1 & 1 \\
\hline & Halichoeres maculipinna (Müller \& Troschel, 1848) 0 & 1 & 1 & 1 & 1 & 1 \\
\hline & Halichoeres radiatus (Linnaeus, 1758) C & 1 & 1 & 1 & 1 & 1 \\
\hline & Thalassoma bifasciatum (Bloch, 1791) A & 1 & 1 & 1 & 1 & 1 \\
\hline \multirow{5}{*}{ Scaridae } & Scarus iseri Bloch, $1789 \mathrm{U}$ & & & & 1 & \\
\hline & Scarus taeniopterus Desmarest, $1831 \mathrm{R}$ & & 1 & & & \\
\hline & Scarus vetula Bloch \& Schneider, $1801 \mathrm{R}$ & 1 & & & & \\
\hline & Sparisoma radians (Valenciennes, 1840) 0 & 1 & 1 & 1 & 1 & \\
\hline & Sparisoma rubripinne (Valenciennes, 1840) C & 1 & 1 & 1 & 1 & \\
\hline
\end{tabular}




\begin{tabular}{|c|c|c|c|c|c|c|}
\hline Gerreidae & Gerres cinereus (Walbaum, 1792) R & 1 & & & & \\
\hline \multirow{2}{*}{ Mullidae } & Mulloidichthys martinicus (Cuvier 1829) R & & & & & 1 \\
\hline & Pseudupeneus maculatus (Bloch, 1793) o & 1 & 1 & 1 & 1 & 1 \\
\hline Pempheridae & Pempheris schomburgkii Müller \& Troschel, 1848 Lc & 1 & & 1 & 1 & 1 \\
\hline Kyposidae & Kyphosus incisor (Cuvier, 1831) C & 1 & 1 & 1 & 1 & 1 \\
\hline \multirow{2}{*}{ Epinephelidae } & Cephalopholis cruentata (Lacepède, 1802) U & & & 1 & & \\
\hline & Epinephelus adscensionis (Osbeck, 1765) C & 1 & 1 & 1 & 1 & 1 \\
\hline Serranidae & Hypoplectrus puella (Cuvier, 1828) R & & & 1 & & \\
\hline Serranidae & Serranus subligarius (Cope, 1870) U & 1 & & 1 & & \\
\hline Apogonidae & Apogon pseudomaculatus Longley $1932 \mathrm{R}$ & & & 1 & & \\
\hline \multirow{3}{*}{ Chaetodontidae } & Chaetodon ocellatus Bloch, 17870 & 1 & 1 & & 1 & 1 \\
\hline & Chaetodon sedentarius Poey, $1860 \mathrm{R}$ & 1 & & 1 & & \\
\hline & Chaetodon striatus Linnaeus $1758 \mathrm{R}$ & 1 & & & & \\
\hline \multirow{2}{*}{ Pomacanthidae } & Holacanthus bermudensis Goode, $1876 \mathrm{R}$ & & & & 1 & \\
\hline & Pomacanthus paru (Bloch, 1787) C & 1 & 1 & 1 & 1 & 1 \\
\hline \multirow{9}{*}{ Haemulidae } & Anisotremus surinamensis (Bloch, 1791) C & 1 & 1 & 1 & 1 & 1 \\
\hline & Anisotremus virginicus (Linnaeus, 1758) C & 1 & 1 & 1 & 1 & 1 \\
\hline & Brachygenys chrysargyreum Günther, $1859 \mathrm{U}$ & 1 & & 1 & & 1 \\
\hline & Haemulon aurolineatum Cuvier, $1830 \mathrm{U}$ & & 1 & & 1 & 1 \\
\hline & Haemulon carbonarium Poey, 18600 & 1 & 1 & 1 & 1 & 1 \\
\hline & Haemulon flavolineatum (Desmarest, 1823) U & 1 & & 1 & & \\
\hline & Haemulon macrostomum Günther, 1859 C & 1 & 1 & 1 & 1 & 1 \\
\hline & Haemulon plumierii (Lacepède, 1801) U & & & 1 & & \\
\hline & Haemulon vittatum Poey, $1860 \mathrm{U}$ & 1 & 1 & & & \\
\hline
\end{tabular}


GSC Biological and Pharmaceutical Sciences, 2020, 12(02), 217-228

\begin{tabular}{|c|c|c|c|c|c|c|}
\hline \multirow{7}{*}{ Lutjanidae } & Lutjanus analis (Cuvier, 1828) U & & & 1 & 1 & \\
\hline & Lutjanus apodus (Walbaum, 1792) 0 & 1 & 1 & & 1 & \\
\hline & Lutjanus griseus (Linnaeus, 1758) 0 & 1 & 1 & 1 & 1 & 1 \\
\hline & Lutjanus jocu (Bloch \& Schneider, 1801) 0 & 1 & & 1 & 1 & 1 \\
\hline & Lutjanus mahogoni (Cuvier, 1828) O & 1 & 1 & 1 & 1 & \\
\hline & Lutjanus synagris (Linnaeus, 1758) 0 & 1 & 1 & 1 & 1 & 1 \\
\hline & Ocyurus chrysurus (Bloch, 1791) 0 & 1 & 1 & 1 & 1 & 1 \\
\hline \multirow{2}{*}{ Scorpaenidae } & Pterois volitans (Linnaeus, 1758) R & 1 & & & & \\
\hline & Scorpaena plumieri Bloch, $1789 \mathrm{U}$ & 1 & & 1 & & 1 \\
\hline Ephippidae & Chaetodipterus faber (Broussonet, 1782) U & & & & 1 & \\
\hline \multirow{3}{*}{ Scianidae } & Odontoscion dentex (Cuvier, 1830) C & 1 & 1 & 1 & 1 & \\
\hline & Pareques acuminatus (Bloch \& Schneider, 1801) 0 & 1 & 1 & 1 & 1 & \\
\hline & Pareques umbrosus (Jordan \& Eigenmann, 1889) 0 & 1 & 1 & 1 & & \\
\hline \multirow{3}{*}{ Acanthuridae } & Acanthurus chirurgus (Bloch, 1787) C & 1 & 1 & 1 & 1 & 1 \\
\hline & Acanthurus coeruleus Bloch \& Schneider, $1801 \mathrm{U}$ & & 1 & 1 & 1 & 1 \\
\hline & Acanthurus tractus Poey, 18600 & 1 & 1 & 1 & 1 & \\
\hline Sparidae & Archosargus probatocephalus (Walbaum, 1792) R & & & & & 1 \\
\hline Monacanthidae & Cantherhines pullus (Ranzani, 1842) o & 1 & 1 & 1 & 1 & 1 \\
\hline \multirow{2}{*}{ Tetraodontidae } & Canthigaster rostrata (Bloch, 1786) C & 1 & 1 & 1 & 1 & 1 \\
\hline & Sphoeroides spengleri (Bloch, 1785) U & & 1 & 1 & & \\
\hline \multirow[t]{2}{*}{ Diodontidae } & Diodon hystrix Linnaeus, $1758 \mathrm{U}$ & 1 & & & 1 & 1 \\
\hline & Total & 69 & 51 & 64 & 57 & 39 \\
\hline
\end{tabular}

The letters at the end correspond to abundance categories: $\mathrm{R}=$ rare, $\mathrm{U}=$ uncommon, $\mathrm{C}=$ common, $\mathrm{O}=$ occasional, $\mathrm{Lc}=$ locally common, and $\mathrm{A}=$ abundant. 
Its composition is similar to that recorded in the Veracruz platform-type reefs $[6,17,18]$. However, the shallow depth of the fringing reefs investigated $(<10 \mathrm{~m})$ may be a limitation for the presence of some common fish species (e. g. Bodianus pulchellus, Prognathodes aculeatus) of areas deeper than $20 \mathrm{~m}$ [19]. Two species from the Indo-Pacific region are included in the list: Pterois volitans and Neopomacentrus cyanomos. The record of $P$. volitans confirms its distribution throughout Veracruz, from the north [18] to the south [20]. A unique observation of lionfish may be an indicator of its population has not yet settled on these reefs. On the other hand, $N$. cyanomos was seen forming groups of 10 to 22 organisms, as well as it has been referred to EnMedio (North) [21] and Palo Seco Reefs (South) on Veracruz [20], its abundance suggested that it is a well-established population. Hypsoblennius invemar, was observed in the exoskeletons of giant barnacle attached to the hull of the Barco Viejo and it is a new record to coral reefs of Veracruz.

The potential richness estimated with non-parametric models was 112 species (Figure 2) and these models explained $81 \%$ of the total richness. The number of species at fringing reefs of southern Veracruz was higher than the records of Pérez-España et al. [6] in Hornos Reef (center of Veracruz). The differences were attributed to the fact that the fringing reefs of southern Veracruz are four times longer than Hornos Reef. The richness of the families Pomacentridae, Haemulidae, Carangidae, and Lutjanidae (Table 1) coincides with that recorded in emerging coral reefs [6, 17, 18]. However, the families: Epinephelidae ( 2 species), Gobiidae ( 2 species), and Scaridae (six species) showed a low richness (Table 1).

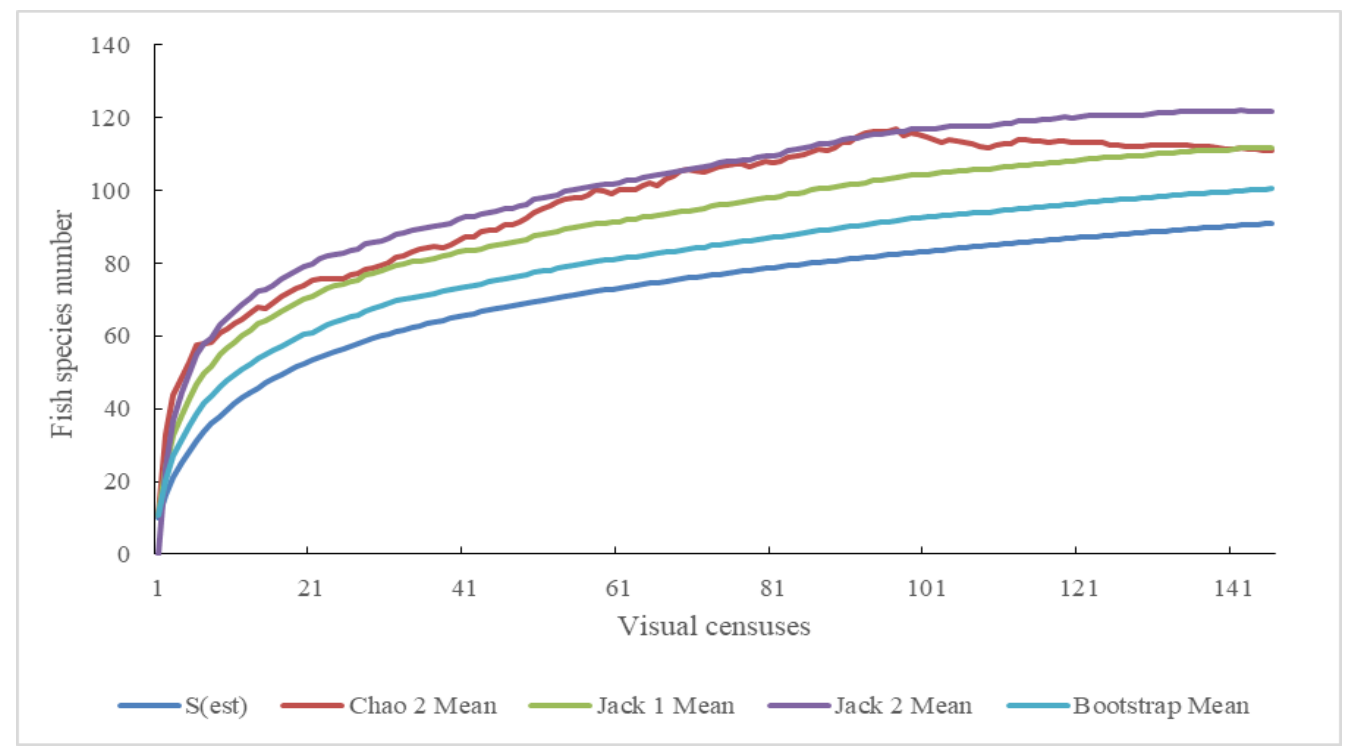

Figure 2 Cumulative curves of the fish richness of fringing reefs of southern Veracruz, Gulf of Mexico according to no parametric models: Chao 2, Jack 1, Jack 2, and Bootstrap.

In the fringing reef system of southern Veracruz 5 habitats were characterized: 1) Rock covered by zoanthids and corals (ROZOCO), characterized by a rock structure covered with Zoanthus pulchellus and/or Palithoa caribaeorum, with isolated coral colonies of the genera Siderastrea and Pseudodiploria as well as sea urchins of the genus Echinometra. This habitat was shallow ( 2 to $4 \mathrm{~m}$ depth) with transparent waters and a low to intermediate structural complexity (Figure 3A); 2) Rock covered with macroalgae and turf algae (ROALGA) formed by hard rock covered with macroalgae (Dyctiota), turf algae, sponges, and sandy areas. The coral cover in this habitat was lesser than $1 \%$, and depth oscillated between 2.5 and $8.5 \mathrm{~m}$. The structural complexity was low in the plains and high in the slopes, while water transparency was high in shallow areas and media in deep areas with more than $5 \mathrm{~m}$ depth (Figure $3 \mathrm{~B}$ and C); 3) Sunken boat (BOAT) locality corresponded to the remains of the boat known as "Barco Viejo" that measures approximately $30 \mathrm{~m}$ in length and located at $6 \mathrm{~m}$ depth. The structural complexity and transparency of the water in this habitat were intermediate (Figure 3 D); 4) Rock covered with macroalgae and corals (ROALCO), was a habitat characterized by a rocky substrate covered with macroalgae (Dyctiota and Galaxaura) or turf algae, with isolated coral colonies (in the shallow parts) of the genera: Siderastrea and Pseudodiploria. The edges slopes that reach up to $8.7 \mathrm{~m}$ depth presented sandy areas. The structural complexity of this habitat was intermediate, and the water transparency was high in shallow areas and media in deep ones (Figure $3 \mathrm{E}$ and F); 5) Coral-covered rock (ROCORA) corresponded to the rocky substrate that forms labyrinths or mountains with sandy channels. It presented colonies of Oculina diffusa, Pseudodiploria clivosa, Pseudodiploria strigosa, and Siderastrea siderea. The depth of this habitat varied between 2.5 and $4.5 \mathrm{~m}$, and its structural complexity was high and presented transparent waters (Figure $3 \mathrm{G}$ and $\mathrm{H}$ ). These habitats were similar to those determined in the shallow parts of platform-type reefs [22, 23]. 


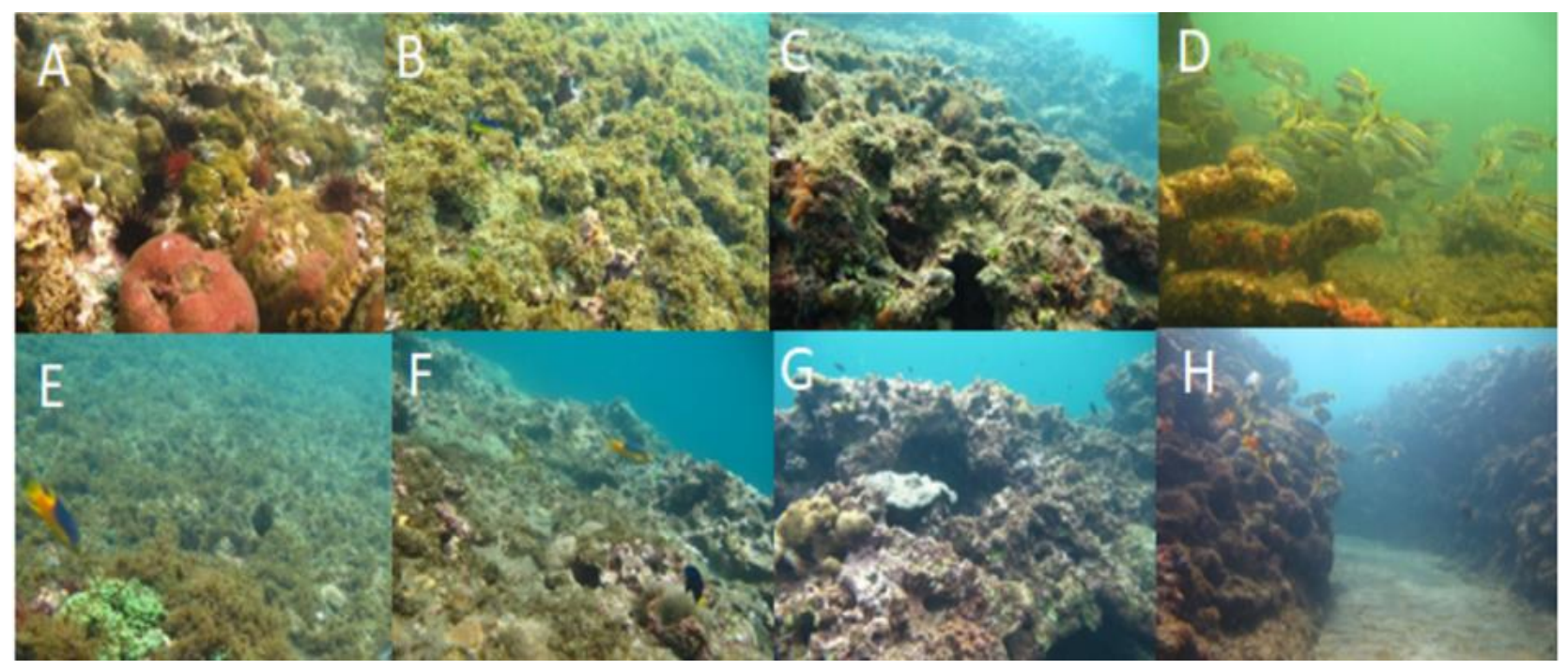

Figure 3 Habitats of the fringing system of southern Veracruz, Gulf of Mexico. A) View of ROZOCO, showing colonies of Z. pulchellus, Siderastrea sp, and Echinometra sp; B) Shallow zone of ROALGA, covered with brown algae (Dyctiota); C) Slope of ROALGA, characterized by turf algae and sponges; D) View of sunken boat known as "Barco Viejo" (BOAT); E) View of the shallow zone of ROALCO, covered with brown algae and small coral colonies; F) Slope of ROALCO with brown algae and coral colonies; G) View of the shallow zone of ROCORA, covered with coral colonies, soft corals and sponges; and H) Labyrinthine channels of ROCORA with sandy areas in the bottom and rock walls.

Table 2 Most abundant fish species by habitat, in the southern fringing reefs of Veracruz, Gulf of Mexico.

\begin{tabular}{|c|c|c|}
\hline Habitat & Shallow zones $(<5 \mathrm{~m})$ & Slopes $(>5 \mathrm{~m})$ \\
\hline ROALGA & $\begin{array}{l}\text { Halichoeres bivittatus, Stegastes adustus, } \\
\text { Bodianus rufus, Labrisomus nuchipinnis, and } \\
\text { Thalassoma bifasciatum. }\end{array}$ & $\begin{array}{l}\text { Schools of roving herbivorous: Acanthurus chirurgus, } \\
\text { Kyphosus incisor, and Sparisoma rubripinne as well as } \\
\text { solitary individuals: Hypoplectrus puella, Chaetodon } \\
\text { sedentarius, and Pareques acuminatus. }\end{array}$ \\
\hline ROZOCO & $\begin{array}{l}\text { Stegastes adustus, Halichoeres bivittatus, } \\
\text { Ophioblennius maclurei, Thalassoma } \\
\text { bifasciatum, and Bodianus rufus. }\end{array}$ & \\
\hline ROALCO & $\begin{array}{l}\text { Halichoeres bivittatus, Stegastes adustus, } \\
\text { Bodianus rufus, Ophioblennius maclurei, and } \\
\text { Sparisoma rubripinne. }\end{array}$ & $\begin{array}{l}\text { On the slopes: Chaetodon ocellatus, Acanthurus } \\
\text { coeruleus and Acanthurus chirurgus. } \\
\text { On the sandy bottom were common: Pareques } \\
\text { umbrosus, Odontoscion dentex, and Serranus } \\
\text { subligarius. }\end{array}$ \\
\hline BOAT & $\begin{array}{l}\text { Anisotemus virginicus, Haemulon } \\
\text { macrostomum, and Pempheris schomburgkii }\end{array}$ & \\
\hline ROCORA & $\begin{array}{l}\text { Stegastes adustus, Microspathodon } \\
\text { chrysurus, Ophioblennius maclurei, } \\
\text { Thalassoma bifasciatum, and Labrisomus } \\
\text { nuchipinnis. In the channels were common: } \\
\text { Haemulon macrostomum, Haemulon } \\
\text { carbonarium, Bodianus rufus, and } \\
\text { Halichoeres bivittatus as well as schools of: } \\
\text { Acanthurus chirurgus, and Abudefduf } \\
\text { saxatilis. }\end{array}$ & \\
\hline
\end{tabular}

The shallow habitats, with transparent waters and low structural complexity (ROZOCO, shallow part of ROALGA, and ROALCO), were less rich (Table 1). The ichthyofauna of these habitats was represented by Halichoeres bivittatus, 
Stegastes adustus, Bodianus rufus, Labrisomus nuchipinnis, Ophioblennius maclurei, Sparisoma rubripinne, Microspathodon chrysurus, and Thalassoma bifasciatum, as is the case in the plains of the platform type reefs [22, 24]. In contrast, deeper and complex habitats (ROALGA, ROCORA, ROALCO) showed greater ichthyological richness. On the slopes, groups of roving herbivores (Acanthurus chirurgus, Kyphosus incisor, and S. rubripinne) and other species that use the structures as a refuge were observed. A special case was the wreck, where the metallic structure favors the presence of haemulids, labrids, and pomacentrids. In this case, the lower richness seems to be related to its area (approximately $100 \mathrm{~m}^{2}$ ), the low structural complexity of the surrounding areas, and the turbidity. The most frequent fish species by reef habitat are shown in Table 2. Extreme environmental conditions may limit the establishment and distribution of ichthyofauna [25], especially of roving herbivores [26, 27].

Jaccard's analysis indicates that the ichthyofaunal components of different habitats were similar. The dendrogram formed 3 groups: one that associated the ROCORA and ROALGA habitats (0.66), another that linked the ROZOCO and ROALCO habitats (0.71), and a third group that corresponded to the BOAT (Figure 4). The similarity of the ichthyofauna of fringing reefs of southern Veracruz is due to their shallowness, structural complexity, and coral cover. The last 2 variables are related to the exposure of fringing reef to the freshwater carried by the streams that originate in the surrounding volcanic zone $[7,28]$ as well as to the high regional precipitation [29] that reduces salinity, increases the availability of nutrients and decreases the transparency of the water, as occurs in Hornos Reef [6].

The analysis of the relative abundance indicated that of the total fish species, $25 \%$ were cataloged as Rare, $25 \%$ as Uncommon, $23.9 \%$ as Occasional, and $22.7 \%$ were Common or Abundant. The highest number of rare fish species was detected in the ROCORA habitat (15.7\%) and the lowest in the ROALCO habitat (1.96\%). These differences were attributed to structural complexity [30]. On the other hand, the highest proportion of locally abundant fish species was observed in the ROALGA area (7.02 \%) due to the presence of schools of A. chirurgus and C. scotti among other species (Table 1).

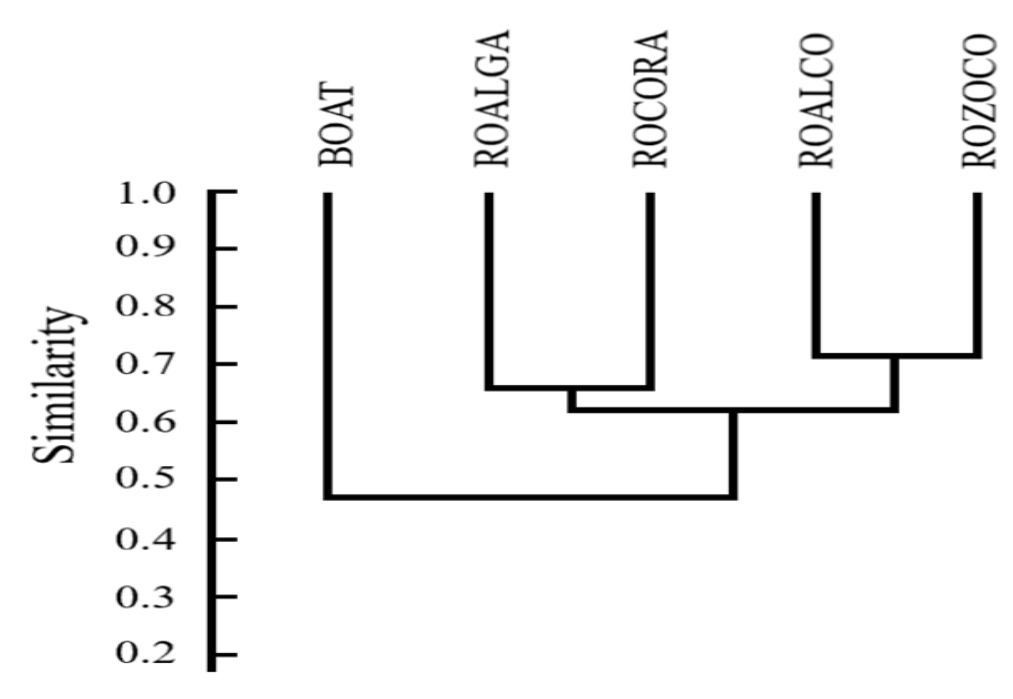

Figure 4 The similarity of fish communities of the fringing system of southern Veracruz, Gulf of Mexico, according to Jaccard's Index.

The scarce richness and abundance of the families: Scaridae, Gobiidae, and Epinephelidae in the fringing reefs of southern Veracruz were similar to the records at Hornos Reef [6]. Among the species with a wide distribution and abundance, highlighted: Epinephelus adscencionis and S. rubripinne, that suggest a close relationship with reef structures $[30,31,32]$ and food availability [33]. The abundance of $S$. rubripinne in the fringing reefs of Veracruz' southern, can be related to its capacity to occupy any reef area (ridge, slope, etc.) together with the fact that it can consume algae of the genera: Halimeda and Dictyota [34] as well as turf algae [35] which are abundant in the region.

Other factors, such as fishing or processes such as recruitment, may be implicated in the richness of the families Epinephelidae and Scaridae. The effect of fishing on scarids is predictable, as, when it intensifies, the biomass decreases due to the absence of large fish [36], and the same is true on epinephelids. Although there are no fishery data for the region, pressure from this factor does not appear to be important because no juvenile or small-sized stages were observed. On the other hand, larval recruitment has been linked to reproduction. The dispersion produced by marine 
currents [37] and possibly the natural barrier (anticyclone gyre) that forms in the summer in front of the SAT [38] as well as the quality of the larvae [37] may limit entry and recruitment of fish larvae in the region.

The results of this research reveal that the components and abundance of fish associated with the reef ecosystems of southern Veracruz are related to at least 3 factors: 1 ) structural complexity, which is a determining in reef fish diversity [31, 32, 39]; 2) river drainage and the regional rainfall regime [28] which decreases salinity and increases water turbidity in the coastal zone. When these coupled with oceanographic dynamics may be unfavorable for fish recruitment and survival $[25,37,40]$; and 3 ) depth, that separates shallow and deep fish associations $[3,19]$.

\section{Conclusion}

The ichthyofauna of the southern fringing reefs of Veracruz was composed of 91 fish species. The richest fish families were: Pomacentridae, Haemuidae, and Lutjanidae. The scarcity of scarids, gobids, and epinephelids was highlighted. The environmental conditions defined by benthic (coral cover) and environmental features (structural complexity, transparency, and depth) in this region seem to be related to composition, distribution, and abundance of fish communities.

\section{Compliance with ethical standards}

\section{Acknowledgments}

This research forms part of the Project "Esponjas, corales escleractinios, equinodermos y peces de los arrecifes coralinos del norte y sur de Veracruz", sponsored by CONABIO (grant number FB1628/JF124/12).

\section{Disclosure of conflict of interest}

The author declare no conflict of interest.

\section{References}

[1] Ortiz-Lozano L, Pérez-España H, Granados-Barba A, González-Gándara C, Gutiérrez-Velázquez A, Martos J. The Reef Corridor of the Southwest Gulf of Mexico: Challenges for its management and conservation. Ocean \& Coastal Management. 2013; 86, 22-32.

[2] Nuñez-Lara E, Arias-González JE, Legendre P. Spatial patterns of Yucatan reef fish communities: testing models using a multi-scale survey design. Journal of Experimental Marine Biology and Ecology. 2005; 324, $157-169$.

[3] Hernández-Landa RC, Acosta-González G, Núnez-Lara E. Arias-González JE. Spatial distribution of surgeonfish and parrotfish in the north sector of the Mesoamerican Barrier Reef System. Marine Ecology. 2014.

[4] Aguilar-Medrano R, Arias-González JE. Functional reef fish groups of the Mexican Caribbean: implications of habitat complexity. Revista Mexicana de Biodiversidad. 2018; 89, 1138-1153.

[5] Stefanoudis PV, Gress E, Pitt JM, Robertson Smith S, Kincaid T, Rivers M, Andradi-Brown DA, Rowlands G, Woodall LC, Rogers AD. Depth-Dependent structuring of reef fish assemblages from the shallows to the rariphotic zone. Frontiers of Marine Science. 2019.

[6] Pérez-España H, Bello-Pineda J, Ávila-Santiago P, Berumen-Solorzano P, Melo-Merino S, Flores-Arévalo RR, Santander-Monsalvo J, GómezVillada RS, Román-Vives MA, Ruiz-Lozano C, Alvarado-Tejeda M, Roldán-Ubando AA, Cabrera-Valenzuela A. Monitoreo del Parque Nacional Sistema Arrecifal Veracruzano: Segunda Etapa. Universidad Veracruzana, Instituto de Ciencias Marinas y Pesquerías. Informe final SNIB-CONABIO, proyecto GM004, México. 2015.

[7] Comisión Nacional de Áreas Naturales Protegidas. Estudio Previo Justificativo para la declaratoria del Área de Protección de Flora y Fauna Arrecifes de Los Tuxtlas. México: CONANP. 2018.

[8] Arriaga-Cabrera L, Vázquez-Domínguez E, González-Cano J, Jiménez-Rosenberg R, Muñoz-López E, Aguilar-Sierra V, coord. Regiones marinas prioritarias de México. México: Comisión Nacional para el Conocimiento y uso de la Biodiversidad. 1998.

[9] Hernández-Pérez JR. Estudio faunísico de los moluscos del arrecife "La Perla del Golfo", Veracruz, México [Degree Thesis]. México: Universidad Nacional Autónoma de México. 2015. 
[10] González-Gándara C, Solís-Marín FA, De la Cruz-Francisco V, A. Granados-Barba A, Salas-Pérez JJ, ArguellesJiménez J, Escárcega-Quiroga PA. Riqueza y distribución de equinodermos en los arrecifes del norte y sur de Veracruz, México. Revista de Biología Tropical. 2015; 63 (Suppl 2): 183-193.

[11] González-Gándara C, De la Cruz-Francisco V. Unusual record of the Indo-Pacific pomacentrid Neopomacentrus cyanomos (Bleeker, 1856) on coral reefs of the Gulf of Mexico. BioInvasions Records. 2014; 3 (1): 49-52.

[12] Nelson JS, Grande TC, Wilson MVH. Fishes of the World. 5th ed. New Jersey: John Wiley \& Sons. 2016.

[13] Fricke R, Eschmeyer WN, van-der-Laan R. Eschmeyer's Catalog of Fishes Online Database [Internet] United States of America: (C) 2020 [cited 2020 April 9].

[14] Froese R, Pauly D, eds. FishBase [Internet] Germany: Calacademy; (C) 2019 [cited 2019 December].

[15] Colwell RK. EstimateS: Statistical estimation of species richness and shared species from samples (Version 9.1) [Internet]. (C) 2019 [cited 2019 May 9].

[16] Hammer $\emptyset$, Harper DAT, Ryan PD. PAST: Paleontological Statistics software package for education and data analysis (Versión 3.25). Palaeontologia Electronica. (2001); 4(1): 1-9.

[17] Del Moral-Flores LF, Tello-Musi JL, Reyes-Bonilla H, Pérez-España H, Martínez-Pérez JA, Horta-Puga G, VelazcoMendoza LA, Alvarez del Castillo-Cárdenas PA. Lista sistemática y afinidades zoogeográficas de la ictiofauna del Sistema Arrecifal Veracruzano, México. Revista Mexicana de Biodiversidad. 2013; 84: 825-846.

[18] González-Gándara C, Lozano-Vilano ML, De la Cruz Francisco V, Domínguez Barradas C. Peces del sistema arrecifal Lobos-Tuxpan, Veracruz, México. Universidad y Ciencia. 2013; 29(2): 191-208.

[19] González-Gándara C. Peces del arrecife Blake, Veracruz, México: Inventario, distribución y afinidades zoogeográficas. Ecosistemas y Recursos Agropecuarios. 2015; 2(4): 87-98.

[20] González-Gándara C. La comunidad de peces del arrecife Palo Seco, Veracruz, golfo de México y su relación con los grupos morfofuncionales. CienciaUAT. 2020; 14(2): 34-50.

[21] De la Cruz-Francisco V, González-González M, Morales-Quijano I. Ampliación del ámbito de distribución geográfica de la especie exótica: Neopomacentrus cyanomos (Bleeker, 1856) (Perciformes-Pomacentridae) en el sistema arrecifal Lobos-Tuxpan, Veracruz, México. Revista de Investigaciones Marinas. 2016; 35(2): $101-108$.

[22] González-Gándara C, Membrillo-Venegas N, Núñez-Lara E, Arias-González JE. Relationship between reef fish communities and reefscapes in Alacranes reef, Yucatan. Vie et Milieu. 1999; 49(4): 275-286.

[23] González-Gándara C, Salas-Pérez JJ. Caracterización del sustrato bentónico del arrecife Tuxpan, Veracruz, México, con énfasis en la comunidad de corales escleractinios. Revista de Biología Marina y Oceanografía. 2019; 54(3): 259-271.

[24] González-Gándara C, Trinidad-Martínez SC, Chávez-Morales VM. Peces ligados a Thalassia testudinum en el arrecife Lobos, Veracruz, México: diversidad y abundancia. Revista de Biología Tropical. 2006; 54(1): $189-194$.

[25] Brandl SJ, Johansen JL, Casey JM, Tornabene L, Morais RA, Burt JA. Extreme environmental conditions reduce coral reef fish biodiversity and productivity. Nature Communications. 2020; 11: 3832.

[26] Nemeth M, Appeldoorn R. The Distribution of Herbivorous Coral Reef Fishes within Fore-reef Habitats: the Role of Depth, Light and Rugosity. Caribbean Journal of Science. 2009; 45(2-3): 247-253.

[27] Cheal AJ, Emslie M, MacNeil MA, Miller I, Sweatman H. Spatial variation in the functional characteristics of herbivorous fish communities and the resilience of coral reefs. Ecological Applications. 2013; 23(1): 174-188.

[28] Pérez-Maqueo O, Muñoz-Villiers L, Vázquez G, Equihua ZE, León RP. Hidrología. In: Cruz-Angón A, ed. La biodiversidad en Veracruz estudio de estado. 1st ed. Xalapa, México: CONABIO, Gobierno de Veracruz, Universidad Veracruzana, Instituto de Ecología. (2011); 289-292.

[29] Gutiérrez-García G, Ricker M. Climate and climate change in the región of Los Tuxtlas (Veracruz, México): A statistical analysis. Atmósfera. 2011; 24(4): 347-373.

[30] Newman SP, Meesters EH, Dryden CS, Williams SM, Sanchez C, Mumby PJ, Polunin NVC. Reef flattening effects on total richness and species responses in the Caribbean. Journal of Animal Ecology. 2015.

[31] Tzadik OE, Appeldoorn RS. Reef structure drives parrotfish species composition on shelf edge reefs in La Parguera, Puerto Rico. Continental Shelf Research. 2013; 54: 14-23. 
[32] Komyakova V, Munday PL, Jones GP. Relative Importance of Coral Cover, Habitat Complexity and Diversity in Determining the Structure of Reef Fish Communities. PLoS ONE. 2020; 8(12): e83178.

[33] Bonaldo RM, Hoey AS, Bellwood DR. The ecosystem roles of parrotfishes on tropical reefs. Oceanography and Marine Biology: An Annual Review. 2014; 52: 81-132.

[34] McAfee ST, Morgan SG. Resource use by five sympatric parrotfishes in the San Bias Archipelago, Panama. Marine Biology. 1996; 125: 427-437.

[35] Randall JE. Food habits of reef fishes of the West Indies. Studies in Tropical Oceanography. 1967; 5: 665-847.

[36] Hawkins JP, Roberts CM. Effects of fishing on sex-changing Caribbean parrothfishes. Biological Conservation. 2003; 115: 213-226.

[37] Fobert EK, Treml EA, Swearer SE. Dispersal and population connectivity are phenotype dependent in a marine metapopulation. Proceedings of Royal Society Publishing. 2019; 286: 20191104.

[38] Salas-Monreal D, Salas-Pérez J, Salas de León DA, Monreal Gómez MA, Pérez-España H, Ortiz-Lozano LD, Granados-Barba A, Riverón-Enzástiga ML, Villegas-Sánchez CA. Corrientes superficiales dentro del corredor arrecifal del Suroeste del Golfo de México. UVSERVA. 2017; 3: 32-36.

[39] Untersteggaber L, Mitteroecker P, Herler J. Coral architecture affects the habitat choice and form of associated gobiid fishes. Marine Biology. 2014; 161: 521-530.

[40] Cowen RK. Larval Dispersal and Retention and Consequences for Population Connectivity. In: Sale PF ed. Coral Reef Fishes Dynamics and Diversity in a Complex Ecosystem. 1st ed. San Diego: Academic Press; $2002 ; 149-170$. 